\title{
A Adesão ao Tratamento da Aids: um Relato de Experiência
}

\author{
Carrijo, Lais Ferreira; Silva, Rodrigo de Paiva Oliveira; Reis, Sandra C. Gumiaraes \\ Bahia \\ Unievangélica — medlaiscarrijo@gmail.com
}

INTRODUÇÃO Os portadores de HIV/Aids vivenciam desafios relacionados à doença, tais como processo terapêutico complexo, visitas médicas periódicas, efeitos colaterais e hospitalizações. a adesão medicamentosa é um dos aspectos mais importantes no tratamento e define o sucesso das intervenções médicas. Diversos estudos têm buscado identificar aspectos da enfermidade, tratamento, da pessoa, participação da equipe cuidadora e características dos serviços de saúde que podem estar relacionados a adesão à Terapia Anti Retroviral. o setor público brasileiro, através do Sistema Único da Saúde (SUS) tem proporcionado o fornecimento de drogas antirretrovirais para seus cidadãos portadores da doença. em Anápolis, o serviço de referência para esse agravo possui o Centro de Testagem e Aconselhamento (CTA) e o Serviço Assistencial Especializado(SAE). OBJETIVOS Relatar a experiência dos alunos de medicina, na visita a uma unidade de saúde, centro de tratamento à AIDS, e analisar aspectos da adesão dos pacientes a terapia Anti Retroviral. MÉTODOS Trata-se de um relato de experiência, baseado em uma visita a uma unidade de saúde, centro de tratamento à AIDS, por alunos de medicina. Utilizou-se do diário de campo e da observação sistemática. Os aspectos norteadores da visita foram as diretrizes da Política Nacional de DST/Aids e a patogenia da doença. RESULTADOS a Aids é uma doença emergente que foi diagnosticada na década de 80 e se configurou como epidemia. Inicialmente acometia homossexuais masculinos e era fatal. com o advento dos medicamentos retrovirais e de sua novas formulações, a sobrevida dos portadores tem sido aumentada. Atualmente é uma doença disseminada em toda a comunidade, e todos apresentam risco de contraí-la. na visita, o processo assistencial dos pacientes foi observado. o acesso aos serviços se dá pelo Centro de Testagem e Aconselhamento (CTA). Os indivíduos, sem pedido médico, podem realizar os exames disponibilizados, que são os testes rápidos para o HIV, hepatites $\mathrm{B}$ e $\mathrm{C}$ e sífilis. Os testes para detecção do HIV podem ser divididos em quatro grupos: detecção de anticorpos, detecção de antígenos, cultura viral e amplificação do genoma do vírus (BRASIL,2006). no CTA, são realizados os testes de anticorpos. uma entrevista de aconselhamento é realizada e um prontuário numerado é aberto para o paciente. Os indivíduos que procuram o serviço são de todas as faixas etárias. no relato dos profissionais, observa-se um aumento no número de idosos. Sugere-se que esse fato se deve ao uso de medicamentos para disfunção erétil, o que aumentou a vida sexual desse grupo e também dificuldades no uso de preservativo (OLIVEIRA,2013). As meninas de 13 a 19 anos também aparecem como demanda em ascensão, na Unidade. Os pacientes diagnosticados com as doenças, são encaminhados para o SAE, para tratamento e acompanhamento.A dispensação medicamentosa é realizada para todos os pacientes, mesmo os que são tratados nas clínicas privadas da cidade. o dispêndio dessa intervenção medicamentosa é sempre evidenciado pelos profissionais, e a continuidade dos retrovirais nos Centros Básico de Saude. um ponto que foi evidenciado foi o cuidado dos profissionais na busca por pacientes faltosos e a dificuldade de adesão dos pacientes ao tratamento. uma caixa repleta de medicamentos vencidos estava na sala. o custo estimado desse 
desperdício foi orçado no valor de um carro popular brasileiro. de acordo com os funcionários, a explicação para o abandono medicamentoso pode estar vinculado às dificuldades psicossociais do indivíduo, aos efeitos colaterais do medicamento, ao tempo indeterminado do tratamento ou mesmo a própria terapia anti retroviral utilizada. CONCLUSÃO o diagnóstico do HIV ainda suscita nas pessoas muitas questões e desafios de natureza psicológica, social, cultural e econômica. do ponto de vista da terapêutica e do tratamento, o momento atual tem mostrado avanços na produção de medicamentos mais potentes, com administração facilitada e com menos efeitos colaterais( BRASIL,2006). a assistência integral aos pacientes, o respeito aos seus direitos e à sua dignidade, ao lado das ações de prevenção, das campanhas, do processo de educação permanente dos profissionais de saúde, da adoção de ações e metas arrojadas têm sido os principais motivos do progresso das respostas, em relação à AIDS (LEITE,2003). a adesão dos pacientes tratados nessa Unidade é um dos aspectos que mais impactou na visita técnica realizada pelos alunos de medicina, em 2013, na disciplina do Programa de Integração em Saúde Coletiva. a adesão medicamentosa, é um processo dinâmico e multifatorial, o qual utiliza-se dos medicamentos prescritos ou outros procedimentos por pelo menos $80 \%$ do total, seguindo regras como horários, doses e tempo de tratamento, coincidindo com a prescrição clínica.

Carrijo, Lais Ferreira; Silva, Rodrigo de Paiva Oliveira; Reis, Sandra C. Gumiaraes Bahia. A Adesão ao Tratamento da Aids: um Relato de Experiência. In: Anais do Congresso Internacional de Humanidades \& Humanização em Saúde [= Blucher Medical Proceedings, num.2, vol.1]. São Paulo: Editora Blucher, 2014. ISSN 2357-7282

DOI 10.5151/medpro-cihhs-10416 